\title{
PEMBERDAYAAN EKONOMI KOPERASI BERBASIS SYARIAH PADA KPRI SMAN I KOTA SOLOK
}

\author{
Afrizul \\ Ekonomi Syariah Program Pascasarjana IAIN Batusangkar \\ e-mail: Afrizul_Fkdtsolok@yahoo.co.id
}

\begin{abstract}
In this article there are three things that become problems, namely about how forms of empowerment, the form of savings and credit business is seen in the sharia perspective and what are the inhibiting factors in sharia-based economic empowerment at the head of KPRI SMAN I Kota Solok. The type of research conducted is field research by using a qualitative approach. The purpose of the research is to find out the forms of empowerment of savings and loan business forms seen in the perspective of sharia what are the inhibiting factors in sharia-based economic empowerment at the head of KPRI SMAN I Kota Solok. Data collection techniques are document and documentation interviews he continued analyzing the data needed with various theoretical basis then read and study. The results of this research shown that Sharia-based forms of empowerment at KPRI Syariah SMAN I Solok City. First, cooperatives have been managed by sharia patterns. Second, savings and loans and Islamic financing that have been given to members have reached $\mathrm{Rp}$. 70,000,000, - (Seventy Million Rupiah). Third, by services / ujrah / ratio / fee of 0.8 agreed with members in each savings and loan and Islamic financing. Fourth, increasing understanding and ability of management and members in managing the cooperative through syariah pattern. Fifth, participating in activities carried out by DEKOPINDA of Solok Regency, at Solok Cooperative and Industry Office and centre of KPRI in West Sumatra Province. Sixth, distributing social funds, rewards for children's members who have good achievements and productive zakat for the surrounding community.
\end{abstract}

Keywords: Empowerment, Economy, Cooperatives

PENDAHULUAN

Pada dasarnya Islam adalah agama pemberdayaan. Dalam pandangan Islam, pemberdayaan harus merupakan gerakan tanpa henti. Hal ini sejalan dengan paradigma Islam sendiri sebagai agama gerakan atau perubahan. Pemberdayaan atau pengembangan adalah upaya memperluas horizon 
pilihan bagi masyarakat. ini berarti masyarakat diberdayakan untuk memilih sesuatu yang bermanfaat bagi dirinya. Dengan memakai logika ini, dapat dikatakan bahwa masyarakat yang berdaya adalah yang dapat memilih dan mempunyai kesempatan untuk mengadakan pilihan-pilihan. (Machendrawaty 2001: 41)

Menurut Agus Efendi, setidaknya ada tiga kompleks pemberdayaan yang mendesak untuk diperjuangkan dalam konteks keumatan masa kini, yakni pemberdayaan dalam tataran ruhaniah, intelektual, dan ekonomi. Dalam kompleks pemberdayaan ekonomi, masalah kemiskinan menjadi demikian identik dengan masyarakat Islam di Indonesia. (Machendrawaty 2001: 44).

Salah satu sistem ekonomi yang saat ini mendapat pengakuan dunia adalah sistem ekonomi Islam atau yang lebih dikenal dengan sistem ekonomi syari'ah. Kajian-kajian ilmiah tentang ekonomi dan keuangan Islam muncul serta mengalami perkembangannya sejak tahun 1970an, baik di Timur Tengah maupun di negara-negara Islam yang lain. Sejak saat itu, sistem ekonomi Islam muncul sebagai wacana dan dipandang sebagai suatu alternatif pilihan.
Perkembangan ekonomi Islam terjadi sejalan dengan kecenderungan yang menguat terhadap pemihakan sistem ekonomi neo-klasik akibat menguatnya anggapan bahwa ekonomi Keynesian sudah tidak lagi mampu menjawab berbagai masalah perekonomian negara-negara kapitalis barat (Zainuddin, 2016: 11)

Ajaran Islam menganjurkan dalam mengembangkan ekonomi tidak boleh menimpakan bahaya atau kerugian pada orang lain (QS Al Muthaffifin, 1-3). Begitu juga, di dalam QS Al Baqarah: 275 dijelaskan pula bahwa segala tambahan atas pinjaman atau tambahan dari pertukaran pada satu jenis barang yang sama atau disebut juga dengan riba dalam ekonomi Islam diharamkan. Sudah menjadi keputusan hampir seluruh ahli fiqih di dunia bahwa tingkat bunga bank masuk dalam kategori riba. Tingkat bunga dalam sistem ekonomi Islam menjadi haram dikarenakan dalam pelaksanaan bunga melakukan tindakan memastikan sesuatu yang tidak pasti.(Rivai, 2010: 155)

Koperasi merupakan salah satu lembaga keuangan non bank yang cukup berperan dalam menumbuh kembangkan perekonomian Indonesia. Koperasi merupakan usaha gerakan rakyat yang 
berdasarkan pada asas kekeluargaan.

Saat ini koperasi di Indonesia sudah berkembang cukup pesat, hal ini dapat dilihat dengan semakin banyaknya jenis koperasi yang didirikan. Perkembangan koperasi yang semakin pesat pun dipengaruhi oleh masayarakat yang semakin mengetahui manfaat dari adanya koperasi yang dapat membantu perekonomian serta mengembangkan kreatifitas masing-masing anggota. Koperasi dalam kegiatannya memiliki dua karakter yang khas yaitu bersifat ekonomi dan berwatak sosial, artinya meskipun dalam pokok usahanya berprinsip ekonomi, koperasi tetap mementingkan pendidikan pengkoperasian bagi anggota dan juga masyarakat (Ninik, 2008:17).

Koperasi sebagai badan usaha yang beranggotakan orang-orang atau badan hukum koperasi dengan melandaskan kegiatannya berdasarkan prinsip koperasi sekaligus sebagai gerakan ekonomi rakyat yang berdasarkan atas asas kekeluargaan. Sehingga mewajibkan para anggotanya untuk saling bekerja sama dan saling tolong-menolong. Dalam rangka pelaksanaan demokrasi ekonomi, koperasi harus makin dikembangkan dan ditingkatkan kemampuannya serta dibina dan dikelola secara efisien, karena koperasi merupakan wadah perekonomian yang sesuai dan sangatlah penting dalam menumbuhkan dan mengembangkan potensi ekonomi rakyat serta dalam mewujudkan kehidupan ekonomi yang bercirikan demokratis, kebersamaan dan kekeluargaan guna memajukan kesejahteraaan anggota pada khususnya dan masyarakat pada umumnya serta ikut membangun tatanan perekonomian nasional dalam rangka mewujudkan masyarakat yang maju, adil dan makmur berdasarkan Pancasila dan Undang- Undang Dasar 1945. (Undang-Undang, No 25, Tahun 1992 Pasal 1, Tentang Perkoperasian.)

Pada bulan Februari 2016 Pemerintah Kota Solok melalui Dinas Koperindakpastam mengadakan pelatihan terhadap seluruh pengurus koperasi yang ada di Kota Solok dalam rangka pembinaan koperasi berpola syariah untuk mewujudkan Kota Solok kota beras serambi madinah. Salah satu koperasi yang terkenal di Kota Solok adalah KPRI Syariah SMAN 1 Kota Solok. Koperasi ini merupakan sebuah koperasi yang beranggotakan para Pegawai Negeri di lingkungan SMAN 1 Kota Solok. KPRI mulai berdiri pada tanggal 27 
Juli 1987 dengan berbadan hukum no. 1164/BH-1987 yang beralamat di Jalan Kihajar Dewantoro No.30 Kota Solok Tlp.(0755) 20667.( Dokumen Company Profile KPRI Syariah SMAN 1 Kota Solok).

Dalam konteks pengelolaan organisasi dan perusahaan, KPRI Syariah SMAN 1 Kota Solok dikelola langsung oleh pengurus dari tahun1987 sampai 2017. KPRI Syariah SMAN 1 Kota Solok dalam realisasi kerja sudah melakukan.Perubahan status KPRI dari pola konvensional menjadi pola syariah pada tanggal 8 Oktober 2016. Atas perubahan tersebut pihak KPRI Syariah SMAN 1 Kota Solok sudah melakukan perubahan Angaran Dasar dan Angaran rumah Tangga dan sudah disosialisasikan kepada seluruh anggota koperasi KPRI Syariah SMAN 1 Kota Solok dalam Rapat Akhir Tahun (RAT) tahun 2016. Semenjak penetapan tersebut segala transaksi simpan pinjam dan pembiayaan yang diberikan kepada anggota sudah dilaksanakan dengan pola syariah.

KPRI Syariah SMAN 1 Kota Solok mempunyai banyak kegiatan yang tidak hanya sebatas pada kegiatan ekonomi, namun juga terdapat kegiatan sosial dan kelembagaan. Hal ini menandakan bahwa KPRI Syariah SMAN 1 Kota Solok mengupayakan kesejahteraan anggota dalam bidang ekonomi melalui berbagai macam kegiatan yang tidak hanya menguntungkan anggota secara materiil, namun juga menguntungkan anggota dari segi keterampilan, kreativitas dan mental. (Dokumen program kerja KPRI Syariah SMAN 1 Kota Solok tahun 2017).

Dalam bidang usaha KPRI Syariah SMAN 1 Kota Solok mempunyai tiga unit usaha yaitu pertama unit simpan pinjam, kedua unit pembiayaan syariah, ketiga usaha penyedian barang kosumsi. Untuk tahun 2016 KPRI Syariah SMAN 1 Kota Solok telah merealisasikan pinjaman pembiayaan untuk anggota biasa dengan nominal Rp. 70.000.000,(Tujuh puluh juta rupiah) dan anggota luar biasa sebesar Rp. 20.000.000,- (Dua puluh juta rupiah) dengan masa ansuran sampai 60 kali pembayaran.Khusus untuk pembiayaan syariah KPRI Syariah SMAN 1 Kota Solok telah merealisasikan pembiayaan syariah untuk pembelian barang atau permodalan bagi anggota biasa dengan nominal Rp. 70.000.000,(Tujuh puluh juta rupiah) dengan masa ansuran sampai 60 kali pembayaran. dan bagi anggota luar 
biasa dengan nominal Rp. 15.000.000,( lima belas juta rupiah).

Perkembangan modal sendiri KPRI Syariah SMAN 1 Kota Solok per 31 desember 2016 berjumlah Rp. 2.509.898.960 dengan 136 orang anggota. Dari observasi awal yang penulis lakukan jumlah koperasi yang ada di Kota Solok 57 namun koperasi yang aktif hanya 43 yang terdiri dari KPRI berjumlah 24, koperasi masyarakat 12, Kopkar berjumlah 7 . Dari 43 koperasi yang aktif di Kota Solok hanya KPRI Syariah SMAN 1 Kota Solok satu-satunya koperasi dengan pola syariah.

\section{KAJIAN TEORITIS}

\section{Pemberdayaan Ekonomi}

Pemberdayaan

ekonomi merupakan suatu komitmen politik untuk mengubah paradigma ekonomi konglomerasi secara bertahap dengan menumbuhkan kegiatan ekonomi lapis bawah. Tujuan pemberdayaan usaha kecil yaitu untuk menumbuhkan dan meningkatkan kemampuan mereka agar mandiri serta berkembang menjadi usaha menengah. (Zulkarnain, 2003: 158).

Pemberdayaan ekonomi juga bisa diartikan sebagai upaya peningkatan profesionalisme dan kinerja pelaku pembangun di daerah, termasuk aparatur, organisasi sosial kemasyarakatan, Lembaga Swadaya Masyarakat (LSM), dunia usaha, dan anggota masyarakat untuk mengatasi berbagai masalah yang dihadapi serta merealisasikan aspirasi dan harapan masyarakat untuk mewujudkan peningkatan kualitas hidup kesejahteraan Masyarakat. (Hafidhudin, 2002: 71)

Pemberdayaan Masyarakat

Pemberdayaan juga dapat diartikan sebagai upaya untuk memenuhi kebutuhan yang diinginkan oleh individu, kelompok dan masyarakat luas agar mereka memiliki kemampuan untuk melakukan pilihan dan mengontrol lingkunganya agar dapat memenuhi keinginan-keinginanya, termasuk aksesbilitasnya terhadap sumberdaya yang terkait dengan pekerjaanya, aktivitas sosialnya, dll. (Totok dan Poerwoko, 2012: 27).

Pemberdayaan berkaitan dengan dua istilah yang saling bertentangan, yaitu konsep berdaya dan tidak berdaya terutama bila dikaitkan dengan kemampuan mengakses dan menguasai potensi dan sumber kesejahteraan sosial. Pemberdayaan masyarakat merupakan aspek pembangunan, hakikat pembangunan nasional 
adalah pembangunan manusia Lembaga keuangan yang berbentuk seutuhnya dan masyarakat bank mencakup Bank Umum Syari'ah seutuhnya, dengan kata lain (BUS) dan Bank Pembiayaan Rakyat memberdayakan masyarakat Syari'ah (BPRS). Sedangkan lembaga mengandung makna keuangan yang bukan berbentuk bank mengembangkan, memandirikan, adalah Unit Usaha Syari'ah (UUS) menswadayakan, dan memperkuat dan Bait al Maal wa al Tamwil (BMT). posisi tawar menawar masyarakat (Nuryadi 2004:160) lapisan bawah terhadap kekuatankekuatan penekanan di segala bidang dan sektor kehidupan. (Totok dan Poerwoko, 2012: 27)

Keluarnya Keputusan Menteri Negara Koperasi dan Usaha kecil dan Menengah Republik Indonesia Nomor 91/kep/IV/KUKM/IX/2004 Di samping itu, juga tentang petunjuk pelaksanaan mengandung arti melindungi dan kegiatan Usaha Koperasi Jasa membela dengan berpihak pada yang Keuangan Syariah merupakan lemah, untuk mencegah terjadinya realisasi yang tumbuh subur dalam persaingan yang tidak seimbang dan ekploitasi atas yang lemah, pentingnya pembangunan masyarakat yang menitikberatkan sektor ekonomi ialah agar masyarakat masyarakat ekonomi Indonesia terutama dalam lingkungan Koperasi dan Usaha Kecil dan Menengah.

Menurut pandangan ulama, dapat meningkatkan kesejahteraan penduduk melalui pertumbuhan koperasi (syirkah ta'uwuniyah) dalam Islam adalah menggunakan akad sektor ini, tanpa mengabaikan musyarakah, yakni suatu perjanjian peranan sektor-sektor lainya, dan sekaligus dapat menurunkan kerja sama antara dua orang atau lebih, di satu pihak menyediakan tingkat kemiskinan penduduk. (Sudjana 2001: 256)

\section{Koperasi Syariah}

Lembaga Keuangan Syari'ah (LKS) terdiri dari dua kelompok lembaga, yakni lembaga keuangan berbentuk bank dan lembaga keuangan berbentuk bukan bank.

modal usaha, sedangkan pihak lain melakukan usaha atas dasar profit sharing menurut perjanjian, dan di antara syarat sah musyarakah itu ialah keuntungan setiap tahun dengan persentase tetap kepada salah satu pihak dari musyarakah tersebut. Macam-macam syirkah. (Ahmad dan Hamid 2008: 125) 
1) Syirkah al amlak adalah dua orang atau lebih memiliki harta bersama tanpa melalui akad syirkah. Syirkah dalam kategori ini terbagi menjadi:

a) Syirkah ihtiyari (perserikatan dilandasi pilihan orang yang berserikat), yaitu perserikatan yang muncul akibat keinginan dua orang atau lebih untuk mengikatkan diri dalam satu kepemilikan. Seperti dua orang bersepakat membeli suatu barang, atau mereka menerima harta hibah dan wasiat.

b) Syirkah jabr yaitu sesuatu yang ditetapkan menjadi milik dua orang atau lebih tanpa kehendak mereka, seperti harta warisan yang mereka terima dari orang yang wafat. Harta syirkah dari seorang yang meninggal dunia secara otomatis menjadi milik bersama para ahli warisnya.

2) Syirkah al uqud adalah syirkah yang akadnya disepakati dua orang atau lebih untuk mengikatkan diri dalam perserikatan modal dan keuntungan. Fuqaha' membagi aluqud ke dalam beberapa jenis :

a) Syirkah al inan syirkah atau kerja sama yang dilakukan antara dua orang atau lebih, dimana masing-masing pihak ikut memberikan dana, terlibat dalam pengelolaan dan berbagi keuntungan dan kerugian. Dalam syirkah al inan, dana yang diberikan, kerja yang dilakukan dan hasil yang diterima oleh masing-masing pihak tidak sama.

b) Syirkah al mufawadlah adalah perserikatan yang modal semua pihak dan bentuk kerjasama yang mereka lakukan baik kualitas dan kuantitasnya harus sama dan keuntungan dibagi rata.

c) Syirkah al abdan (syirkah al a'mal) perserikatan dalam bentuk kerja (tanpa modal) untuk menerima pekerjaan secara bersama-sama dan berbagi keuntungan.

d) Syirkah al wujuh merupakan perserikatan yang dilakukan oleh dua orang atau lebih yang memiliki reputasi (dikenal baik) di kalangan masyarakat untuk hutang barang, kemudian menjual dan membagi labanya secara bersama-sama menurut kesepakatan. Praktek dari syirkah jenis ini pada zaman sekarang mirip dengan praktek makelar. Dimana seseorang dipercaya untuk menjualkan barangnya, dan hasil dari penjualan tersebut 
dibagi sesuai dengan kesepakatan.

\section{Pembiayaan}

Keputusan Menteri Keuangan (Menkeu) No.1251/KMK.013/1988 dalam lingkup pembiayaan konsumen dijelaskan bahwa yang dimaksud pembiayaan adalah pembiayaan yang diberikan kepada konsumen untuk melakukan pembelian barang yang pembayarannya dilakukan secara berkala atau angsuran. Berdasarkan UU No. 7 tahun 1992, yang dimaksud pembiayaan adalah penyediaan uang atau tagihan atau yang dapat dipersamakan dengan itu berdasarkan tujuan atau kesepakatan pinjam meminjam antara bank dengan pihak lain yang mewajibkan pihak peminjam untuk melunasi hutangnya setelah jangka waktu tertentu ditambah dengan sejumlah bunga, imbalan atau pembagian hasil.

Menurut PP No. 9 Tahun 1995, tentang pelaksanaan simpan pinjam oleh koperasi, pengertian pinjaman adalah penyediaan uang atau tagihan yang dapat dipersamakan dengan itu, berdasarkan tujuan atau kesepakatan pinjam meminjam antara koperasi dengan pihak lain yang mewajibkan pihak peminjam untuk melunasi hutangnya setelah jangka waktu tertentu dengan disertai pembayaran sejumlah imbalan". (UU No. 9 Tahun 1995. Tentang Perkoperasian).

Prinsip analisis pembiayaan adalah pedoman-pedoman yang harus diperhatikan oleh pengelola bank syariah pada saat melakukan analisis pembiayaan. Secara umum, prinsip analisis pembiayaan didasarkan pada rumus 5C, yaitu:

a. Character artinya sifat atau karakter nasabah pengambil pinjaman.

b. Capacity artinya kemampuan nasabah untuk menjalankan usahadan mengembalikan pinjaman yang diambil.

c. Capital artinya besarnya modal yang diperlukan pinjaman.

d. Collateral artinya jaminan yang telah dimiliki yang diberikan peminjaman kepada bank.

e. Condition artinya keadaan usaha atau nasabah prospek atau tidak

Selain dengan menggunakan 5C dalam menganalisis pembiayaan juga terdapat 7P diantaranya adalah sebagai berikut: (Kasmir, 2005 : 106)

a. Personalit yaitu menilai nasabah dari segi kepribadiannya atau tingkah lakunya sehari-hari maupun masa lalunya. Personality juga mencakup sikap, emosi, tingkah laku dan tindakan nasabah dalam menghadapi suatu masalah. 
b. Party yaitu mengklasifikasikan nasabah ke dalam klasifikasi tertentu atau golongan-golongan tertentu berdasarkan modal, loyalitas serta karakternya. Sehingga nasabah dapat digolongkan kegolongan tertentu dan akan mendapatkan fasilitas kredit yang berbeda pula dari bank.

c. Purpose yaitu untuk mengetahui tujuan nasabah dalam mengambil kredit, termasuk jenis kredit yang diinginkan nasabah. Tujuan pengambilan kredit dapat bermacam- macam apakah untuk modal kerja atau investasi, konsumtif atau produktif dan lain sebagainya.

d. Prospect yaitu untuk menilai usaha nasabah dimasa yang akan datang apakah menguntungkan atau tidak, atau dengan kata lain mempunyai prospek atau sebaliknya. Hal ini penting mengingat jika suatu fasilitas kredit yang dibiayai tanpa mempunyai prospek, bukan hanya bank yang rugi tapi nasabah juga.

e. Payment merupakan ukuran bagaimana cara nasabah mengembalikan kredit yang telah diambil atau sumber mana saja dana untuk pengembalian kredit yang diperoleh. Semakin banyak sumber penghasilan debitur maka akan semakin baik. Sehingga jika salah satu usahanya merugi akan dapat ditutupi oleh sektor lainnya.

f. Profitability untuk menganalisis bagaimana kemampuan nasabah dalam mencari laba. Profitability diukur dari periode ke periode apakah akan tetap sama atau akan semakin meningkat, apalagi dengan tambahan kredit yang akan diperolehnya.

g. Protection, tujuannya adalah untuk menjaga agar usaha dan jaminan mendapatkan perlindungan. Perlindungan dapat berupa jaminan barang atau orang atau jaminan asuransi.

\section{METODE PENELITIAN}

\section{Jenis Penelitian}

Penelitian ini menggunakan metode penelitian kualitatif (field research) yaitu penelitian yang datanya diambil dari lapangan melalui pengamatan, baik pengamatan lansung maupun tidak. Penelitian yang bermaksud memahami fenomena tentang apa yang dialami oleh subjek penelitian. Instrumen utama dalam penelitian ini adalah peneliti sendiri dibantu dengan intrumen pendukung seperti 
Recorder, Field-notes, smart phone dan kamera, pedoman wawancara.

Teknik Pengumpulan Data

Untuk memperoleh data yang lengkap dalam melakukan analisis data dan pengolahan data maka digunakan beberapa metode dan alat pengumpulan data sebagai berikut: Observasi, Dalam penelitian ini, peneliti melihat secara langsung keadaan dan suasana kegiatan di KPRI Syariah SMAN 1 Kota Solok Dengan pengamatan ini diharapkan dapat melengkapi data dari wawancara. Observasi awal dilakukan saat penulis mengajukan rancangan proposal tesis. Peneliti melakukan pengamatan dan pencatatan data secara sistematik terhadap unsur-unsur yang tampak dalam suatu gejala pada objek penelitian dengan melihat pedoman sebagai instrumen pengamatan yang ditujukan untuk meneliti Upaya Pemberdayaan Ekonomi Koperasi Berbasis Syariah Pada KPRI Syariah SMAN 1 Kota Solok, Wawancara.Wawancara yang akan penulis lakukan dengan cara tanya jawab langsung dengan pihak pengurus dan manager KPRI Syariah SMAN 1 Kota Solok), Dokumentasi. Dalam hal ini dokumentasi yang digunakan untuk mendapatkan datadata tertulis tentang masalan penelitian ini, baik berbentuk dokumen pembiayaan, brosur, maupun data lainya seperti profil koperasi, program kerja, serta kondisi fisik KPRI Syariah SMAN 1 Kota Solok.

\section{Teknik Analisis Data}

Analisis data merupakan penafsiran penelitian terhadap data yang telah diolah yang memberikan uraian atau gambaran secara tertulis. Dalam hal ini, penulis menggunakan analisis secara deskriptif kualitatif dengan menguraikan dan menggambarkan secara tertulis Upaya Pemberdayaan Ekonomi Koperasi Berbasis Syariah Pada KPRI Syariah SMAN 1 Kota Solok agar mendapatkan gambaran secara umum tentang masalah yang penulis teliti, kemudian diklasifikasikan dengan aspek masalah yang telah disusun untuk selanjutnya dianalisa dan disimpulkan.

\section{Teknik Penjaminan Keabsahan Data}

Penjaminan keabsahan data merupakan data hasil dari penelitian yang dilakukan sesuai dengan sebenarnya. Kriteria keabsahan data ada empat macam yaitu: derajat kepercayaan (credibility), keteralihan (transferability), kebergantungan (dependability), dan kepastian (confirmability). Dalam penelitian 
kualitatif ini memakai 2 macam antara lain (Moleong, 2006, p.324326).:

\section{Kepercayaan (credibility)}

Kredibilitas data dimaksudkan untuk membuktikan data yang berhasil dikumpulkan sesuai dengan sebenarnya.

2. Kebergantungan (dependability)

Kriteria ini digunakan untuk menjaga kehati-hatian akan terjadinya kemungkinan kesalahan dalam mengumpulkan dan menginterprestasikan data sehingga data dapat dipertanggung jawabkan secara ilmiah.

\section{HASIL DAN PEMBAHASAN}

Hasil

Bentuk pemberdayaan berbasis syariah pada KPRI Syariah SMAN I Kota Solok Pertama, koperasi telah dikelola dengan pola syariah terhitung sejak pembukuan bulan 8 Oktober 2016; Kedua, simpanpinjam dan pembiayaan syariah yang telah diberikan kepada anggota telah mencapai Rp. 70.000.000,- ( Tujuh Puluh Juta Rupiah); Ketiga, dengan jasa/ujrah/nisbah/fee sebesar 0,8 yang disepakati dengan anggota dalam setiap simpan pinjam dan pembiayaansyariah, Keempat, meningkatkan pemahaman dan kemampuan pengurus dan anggota dalam pengelolaan koperasi dengan pola syariah baik yang diadakan oleh KPRI SMAN 1 Kota Solok atau pihak terkait dengan mengikutsertakan pengurus atau anggota dalam kegiatan sosialisasi, pendidikan dan pelatihan dan studi banding ke koperasi yang telah dikelola dengan pola syariah; Kelima, berpartisipasi dalam kegiatan yang dilakukan oleh DEKOPINDA Kota Solok, Dinas Koperasi danPerindusrtian Kota Solok dan KPRI Pusat diProvinsi Sumatera Barat; Keenam,mendistribusikan dana sosial, reward bagi anak anggota yang berprestasi dan zakat produktif bagi masyarakat sekitarnya.

Bentuk Usaha simpan pinjam dilihat dalam perspektif syariah pada KPRI Syariah SMAN I Kota Solok adalah telah merealisasikan peminjaman danpembiayaan untuk anggota biasa dengan nominal Rp. 70.000.000 dan anggota luar biasa dengan nilai nominal maksimal Rp. 20.000.000 dengan masa angsuran sampai 60 kali pembayaran. Dengan mengunakan akad murabahah bil wakalah, Hawalah bil Ujrah, Akad Ijarah, akad Ijarah bil hawalah, akad multi jasa ijarah.Pembiayaan syariah telah bisa 
merealisasikan pembiayaan syari'ah untuk pembelian barang atau permodalan bagi anggota biasa dengan nominal Rp.70.000.000 dan anggota luar biasa dengan nilai nominal maksimal Rp. 15.000 .000 dengan masa angsuran sampai 60 kali pembayaran.Dengan mengunakan Akad Mudharabbah Musyarakah, AkadMudharabbah Musyarakah dan Hawalah, Deposito wal mudharabah.Usahapenyediaan barang konsumsiUsaha ini dapat melayani kebutuhan anggota terhadap barang konsumsi yang masuk ke SMA N 1 Solok.dengan mengunakan akad Qard wal Ijarah, Qard simpanan tanpa jasa.

Faktor penghambat dalam pemberdayaan ekonomi berbasis syariah pada KPRI Syariah SMA I Kota Solok adalah pertama dalam peningkatan disiplin dan kesejahteraan karyawan belum berjalan dengan baik dimana pengisian daftar hadir karyawan belum terlaksana dengan baik,serta belumterealisasinya honor karyawan sesuai denganstandar UMR Kota Solok. Kedua Status AD/ART secara badan hukum masih belum dilakukan oleh pengurus sampai saat ini pengurus masih berusaha untuk mencari regulasi yang tepat dan tidak menyalahi peraturan yang ada kepada

pihak-pihak

yang

terkait.Ketiga masih adanya anggota koperasi

yang tidak menggunakan programpemberdayaan yang telah disediakan oleh operasi diantaranya simpam pinjam kepada anggota, program layanan pembayaran air, listrik, BPJS, jual beli barang kebutuhan sekolah.

\section{PEMBAHASAN}

Pemberdayaan berasal dari penerjemahan bahasa Inggris yaitu "empowerment" yang bermakna "pemberian

kekuasaan".Pemberdayaan kata dasarnya adalah daya, yang artinya kemampuan melakukan sesuatu atau kemampuan bertindak, kekuatan, tenaga yang menyebabkan sesuatu bergerak, muslihat, akal, ikhtiar, dan upaya, kemudian berdaya artinya berkekuatan, bekemampuan, bertenaga, mempunyai akal atau cara untuk mengatasi sesuatu. (Wrihatnolo 2007: 2).Adapun upaya yang dilakukan untuk mengatasi hambatan dalam pemberdayaan menurut Fenti Afriza Agusril selaku bendahara KPRI Syariah SMAN I Kota Solok menjelaskan bahwa pertama : melakukan kerjasma dengan 
pengusaha taylor yang ada di Kota Solok dan menuangkanya dalam bentuk surat perjanjian kerja sama untuk pengadaan pakaian seragam dan atribut perserta didik baru. Kedua selalu mengupayakan pemberian harga yang sama terhadap persedian kebutuhan seragam sekolah peserta didik baru.

Ekonomi koperasi adalah badan usaha yang beranggotakan orang-orang/badan hukum koperasi dengan melandaskan kegiatannya berdasarkan prinsip koperasi sekaligus sebagai gerakan ekonomi rakyat yang berdasarkan atas azaz kekeluargaan (UU nomor 25 tahun 1992 bab I pasal 1).Upaya tersebut dilakukan dengan selalu memperhatikan harga pasar sehingga anggota koperasi lebih sering mengunakan jasa dan barang yang disediakan oleh KPRI Syariah SMAN I Kota Solok.

Analisis

Menurut penulis Upaya Penguatan KPRI Syariah SMAN I Kota Solok Dalam Rangka Pemberdayaan ekonomi KPRI Syariah SMAN I Kota Solokyang merupakan satu-satunya Koperasi pegawai negeri dengan pola syariah tentunya cukup mudah dan dipercaya memperoleh dana dari pihak lain.Hal ini disebabkan KPRI syariah SMAN I Kota Solok sudah cukup punya kemampuan dalam memenuhi standar atau criteria pembiayaan, dan memiliki kemampuan untuk mengembalikan modal pihak lain.Disamping mengadakan kerjasama dengan pemerintah, KPRI Syariah SMAN I Kota Solok juga dapat mengupayakan kerjasama dengan pihak-pihak lain seperti kerjasama antar koperasi,lembaga keuangan syariah maupunsektor swasta yang ada di Kota solok.

Dalam hal ini KPRI Syariah SMAN 1 Kota Solok juga dapat membangun kerjasama dengan koperasi lain ditujukan untuk meningkatkan kapasitas usaha.Untuk mewujudkan hal tersebut KPRI Syariah SMAN 1 Kota Solok dapat ikut serta dalam forum dialog atau asosiasi koperasi ditingkat lokal, nasional, dan internasional. Hal ini ditujukan agar KPRI Syariah SMAN 1 Kota Solok dapat memberikan masukan terhadap rencana pengembangan jaringan usaha koperasi berbasis syariah.

Keberadaan KPRI Syariah SMAN 1 Kota Solok sangat dirasakan manfaatannya oleh anggota namun belum banyak dirasakan manfaatnya 
oleh masyarakat disekitarnya,

dalam setiap simpan pinjam dan kendatipun dalam pemberdayaan KPRI Syariah SMAN 1 Kota Solok sudah pembiayaan syariah Keempat, melaksanakan program pelayanan meningkatkan pemahaman dan pembayaran listrik, air dan BPJS. Upaya lain yang perlu dilakukan pengurus untuk menambah minat anggota koperasi menggunakan jasa yang ditawarkan koperasi adalah dengan menambah ruangan khusus untuk program pelayanan pembayaran, listrik, air dan BPJS sehingga pelayanan tersebut bukan hanya bisa dinikmati oleh anggota koperasi saja akan tetapi juga bisa dinikmati oleh masyarakat di sekitar lingkungan KPRI Syariah SMAN I Kota Solok.

$$
\text { kemampuan pengurus dan anggota }
$$
dalam pengelolaan koperasi dengan pola syariah baik yang diadakan oleh KPRI SMAN 1 Kota Solok atau pihak terkait dengan mengikutsertakan pengurus atau anggota dalam kegiatan sosialisasi, pendidikan dan pelatihan dan studi banding ke koperasi yang telah dikelola dengan pola syariah; Kelima, berpartisipasi dalam kegiatan yang dilakukan oleh DEKOPINDA Kota Solok, Dinas Koperasi dan Perindusrtian Kota Solok dan KPRI Pusat di Provinsi Sumatera Barat; Keenam, mendistribusikan dana sosial, reward

\section{PENUTUP}

\section{Simpulan}

Bentuk- bentuk pemberdayaan berbasis syariah pada KPRI Syariah SMAN I Kota Solok Pertama, koperasi telah dikelola dengan pola syariah terhitung sejak pembukuan bulan 8 Oktober 2016; Kedua, simpan pinjam dan pembiayaan syariah yang telah diberikan kepada anggota telah mencapai Rp. 70.000.000,- (Tujuh Puluh Juta Rupiah); Ketiga, dengan jasa/ujrah/nisbah/fee sebesar 0,8 yang disepakati dengan anggota bagi anak anggota yang berprestasi dan zakat produktif bagi masyarakat sekitarnya.

\section{Saran}

Dalam kesempatan ini penulis memberikan saran yaitu Kepada pengurus, pengawas,pengelola dan anggota KPRI Syariah SMAN I Kota Solok lebih kreatif dalam pemberdayaan ekonomi anggota berbasis syariah. Berupaya untuk lebih mengoptimalkan peran koperasi sebagai suatu badan hukum yang berasaskan kebersamaan, kerakyatan 
serta kemandirian, Kepada pemerintah daerah khususnya Dinas Koperindagpastam Kota Solok untuk lebih meningkatkan perkembangan koperasi dengan pola syariah yang berada dalam ruang lingkup kewenangganya, Bagi lembaga keuangan syariah yang ada di Kota solok agar lebih mengutamakan kerja sama dengan koperasi- koperasi berbasis syariah yang ada di Kota Solok agar koperasi berbasis syariah dapat berkembang dengan pesat di Kota Solok

\section{KEPUSTAKAAN ACUAN}

Ahmad Rodoni dan Hamid Abdul, 2008, Lembaga Keuangan Syariah, Zikrul Hakim, Jakarta,

Hafidhudin, Didin.202. Zakat dalamperekonomian Modern. Jakarta : Gema Insani Press.

Kasmir. 2000. Bank dan lembaga keuangan lainya. Jakarta : Rajawali Pers

Machendrawaty Nanih, 2001, Pengembangan Masyarakat Islam, (Bandung: PT Remaja Rosdakarya.

Ninik Widiyanti dan Sunindhia,Y. W, 2008, Koperasi dan Perekonomian
Indonesia, (Jakarta: Rineka Cipta, Salemba Empat.)

Nuryadi, Ahmad. 2002. Konsep Figh tentang Riba, Gharar, dan Maysir. Makalah Treninig Figh Ekonomi Islam. Cies FE Universitas Airlangga, Surabaya.

Pusat Bahasa. (2008). Kamus Besar Bahasa Indonesia. Jakarta: PT Gramedia Pustaka Utama

Randy R. Wrihatnolo dan Nugroho Dwidjowijoto Rianto , 2007, Manajemen Pemberdayaan: Sebuah Pengantar dan Panduan untuk Pemberdayaan Masyarakat, (Jakarta: PT Elex Media Komputindo,)

Rivai Veithzal, 2010, Islamic Banking Sebuah Teori, Konsep, dan Aplikasi, Penerbit Bumi Aksara, Jakarta

Sudjana. (2001). Pendidikan Luar Sekolah. Bandung: Falah Production

Totok dan Poerwoko. (2012). Pemberdayaan Masyarakat dalam Prespektif Kebijakan Publik. Bandung: Alfabeta.

Undang-Undang, No 25, Tahun 1992 Pasal 1, Tentang Perkoperasian. 
Undang-Undang, No 09, Tahun 1995 Zulkarnain, 2003. Membangun Ekonomi Pasal 1, Tentang Perkoperasian.

Zainuddin Muhadi, 2016, Menyoal Rakyat, Edisi Pertama, Adicita Regulasi Koperasi Syariah, dari KJKS ke KSPPS, Jakarta 